\title{
Epistemological violence, essentialization, dan tantangan etik dalam penelitian psikologi
}

\author{
Monica Eviandaru Madyaningrum* \\ Fakultas Psikologi, Universitas Sanata Dharma, Daerah Istimewa Yogyakarta
}

\begin{abstract}
Abstrak
Tulisan ini hendak membahas persoalan etik dalam penelitian psikologi sosial di Indonesia, yang sejauh ini masih jarang dikaji. Secara khusus, tulisan ini dibangun dengan mengacu pada konsep epistemological violence. Merujuk pada konsep tersebut, penulis berargumen bahwa penelitian psikologi sosial di Indonesia memiliki risiko etis untuk mereproduksi kekerasan epistemologis melalui penggunaan cara pandang yang bersifat essentializing. Mengacu pada argumen ini, penulis mengajukan dua rekomendasi. Pertama, pada tataran personal, penulis memandang pentingnya mengembangkan refleksivitas sebagai sarana untuk mengasah kepekaan etis peneliti. Kedua, terkait dengan peran asosisasi psikologi sosial, penulis berpendapat tentang perlunya asosiasi untuk mendorong diskursus yang lebih kritis tentang etik penelitian dalam studi-studi psikologi sosial di Indonesia.
\end{abstract}

Kata kunci: etik penelitian, epistemological violence, essentialism, reflexivity

\begin{abstract}
This paper aims to examine ethical issues in socio-psychological research in Indonesia, which have been limitedly discussed. The arguments built in this paper are particularly anchored in the concept of epistemological violence. Drawing on this concept, the author argues that socio-psychological research in Indonesia may have an ethical risk of reproducing epistemological violence through the use of essentializing approaches. Informed by this argument, this paper proposes two suggestions. Firstly, on a personal level, the author argues about the importance of developing a researcher's reflexivity to promote better ethical awareness in research practices. Secondly, at the organizational level, this paper underlines the urgency for Indonesian social psychologists and associations to expand scholarly literature and forums that may promote critical perspectives on research ethics.
\end{abstract}

Keywords: research ethics, epistemological violence, essentialism, reflexivity

\section{Pendahuluan}

Memastikan penelitian dilakukan secara etis merupakan salah satu kriteria pokok untuk menentukan kualitas sebuah riset dan kredibilitas seorang peneliti (Israel, 2014; Mertens \& Ginsberg, 2009; Nagy, 2011). Namun demikian, etik penelitian sebagai wacana maupun praktek yang terlembagakan, masih sangat minim dikembangkan di Indonesia Hal ini misalnya terlihat dari masih langkanya literatur tentang etik penelitian, yang ditulis dengan mengacu pada konteks dan praktek penelitian psikologi di Indonesia, termasuk dalam ranah psikologi sosial.

Dalam sejumlah referensi tentang etik psikologi (HIMPSI, 2010; Sutojo \& Hidayat, 2018), pembahasan tentang etik penelitian cenderung bersifat umum, sehingga kurang mampu menggali kompleksitas penerapan prinsip-prinsip etik penelitian di lapangan. Meski referensi dan buku ajar tentang metodologi penelitian psikologi yang ditulis

Naskah masuk: 29 Januari 2020

Naskah diterima: 9 Mei 2020 oleh akademisi Indonesia sudah semakin banyak (Azwar, 2017; Reza, 2016; Supratiknya, 2015), tetapi etik penelitian masih jarang atau hanya sekilas dibahas dalam referensi tersebut. Hal ini menegaskan perlunya kajian yang lebih banyak tentang etik penelitian, terlebih yang secara khusus membahas etik dalam riset-riset psikologi sosial.

Secara umum, etik profesi dimaknai sebagai moralitas atau tata nilai yang mengatur kepantasan sikap dan perilaku dalam cara orang menjalankan pekerjaannya (HIMPSI, 2010; Knapp \& VandeCreek, 2006; Nagy, 2011). Dalam konteks penelitian, ada sejumlah prinsip etis yang menjadi acuan universal bagi para peneliti. Diantaranya adalah prinsip beneficence (melakukan penelitian yang bermanfaat) dan non-maleficence (tidak merugikan atau membahayakan individu yang dilibatkan dalam penelitian) (King, 2010; Knapp \& VandeCreek, 2006). Meski prinsip-prinsip tersebut telah menjadi acuan universal, tetapi pemaknaan dan operasionalisasinya

\footnotetext{
* Fakutas Psikologi, Universitas Sanata Dharma Jl. Paingan, Kab. Sleman, D. I. Yogyakarta, 55281 E-mail: memadyaningrum@usd.ac.id
} 
akan terus berevolusi mengikuti perkembangan tata nilai dan norma yang ada di masyarakat (Mertens \& Ginsberg, 2009; Nagy, 2011; Sutojo \& Hidajat, 2018). Akibatnya, dalam menilai etis atau tidaknya sebuah riset, penting bagi seorang peneliti untuk melibatkan pertimbangan-pertimbangan yang lebih kompleks daripada sekedar mengacu pada prinsip-prinsip umum etik penelitian. Berangkat dari pemikiran semacam inilah, sejumlah akademisi mengajukan argumen tentang perlunya pendekatan dan acuan non-konvensional untuk mengkaji etik penelitian (Cannella \& Lincoln, 2011; Israel 2014; Mertens, Harris \& Holmes, 2009; Sikes, 2013; Teo, 2015, 2018).

Dalam artikel ini, penulis secara khusus menggunakan konsep epistemological violence yang diajukan oleh Teo (2008, 2010, 2011a, 2011b). Konsep ini menawarkan perspektif non-konvensional untuk merefleksikan persoalan etik dalam sejumlah studi psikologi sosial di Indonesia. Istilah psikologi sosial dalam tulisan ini merujuk pada area atau topik studi yang biasanya menjadi bahasan utama dalam pengajaran dan penelitian psikologi sosial, seperti misalnya soal identitas dan relasi sosial (Milla, Abidin, \& Pitaloka 2018; Sarwono \& Meinarno, 2009). Dalam artikel ini, penulis secara khusus menyoroti penelitian yang membahas tentang identitas sosial dan kaitannya dengan persoalan prasangka dan diskriminasi. Argumen-argumen dalam tulisan ini dibangun dari hasil refleksi atas pengalaman pribadi penulis, serta amatan pada sejumlah karya tulis wajib (misalnya, skripsi, tesis) dan artikel jurnal (peer-reviewed) yang diterbitkan di Indonesia.

Ada tiga bagian utama dalam tulisan ini. Pertama, penulis secara sekilas memaparkan perkembangan kajian akademis tentang etik penelitian. Selanjutnya penulis membahas konsep epistemological violence dan mengaitkannya dengan kecenderungan essentialism dalam sejumlah penelitian psikologi sosial di Indonesia. Terakhir, penulis mendiskusikan tentang pentingnya mempraktekkan dan mempromosikan perspektif etik penelitian yang kritis, baik pada tataran personal maupun kolektif.

\section{Etik penelitian dalam studi sosial-humaniora: Lebih dari procedural ethics}

Secara umum, ada lima prinsip dasar yang biasa digunakan untuk memastikan penelitian dilakukan secara etis. Kelima prinsip tersebut adalah: (1) memastikan partisipasi bersifat sukarela dan didasari pemahaman yang memadai tentang penelitian yang akan dilakukan (informed consent); (2) menghindari segala bentuk penipuan atau pengelabuan terhadap partisipan penelitian (no deception); (3) memberikan hak kepada partisipan untuk mengundurkan diri tanpa konsekuensi merugikan (right to withdraw); (4) memastikan partisipan bisa mendapatkan informasi dan dukungan yang diperlukan selama dan sesudah penelitian (debriefing); dan (5) memastikan terjaganya kerahasiaan identitas serta data yang diberikan oleh partisipan (confidentiality) (HIMPSI, 2010; King, 2010; Nagy, 2011).

Secara keseluruhan, kelima prinsiptersebut merujuk pada tuntutan untuk melakukan riset secara kompeten, penuhintegritas, dan menggunakan cara-cara yang menghargai hak serta martabat partisipan penelitian (King, 2010; Nagy, 2011). Guillemin dan Gillam (2004) menggunakan istilah "procedural ethics" untuk menerangkan penerapan kelima prinsip di atas dalam praktek penelitian. Disebut procedural ethics karena kelima prinsip tersebut cenderung berfokus pada aspek prosedural dari bagaimana sebuah riset dilakukan (misalnya, bagaimana partisipan direkrut, bagaimana partisipan diperlakukan dan bagaimana data dikumpulkan). Namun demikian, persoalan dan tantangan etis dalam sebuah penelitian seringkali tidak hanya terbatas pada aspek proseduralnya. Isu dan problem etis dapat muncul dari konteks yang lebih luas, terkait implikasi sosial, politis, atau kultural dari penelitian yang dilakukan (Cannella \& Lincoln, 2011; Sikes, 2013; Teo, 2018; Teo, Gao, Sheivari, 2014).

Cannella dan Lincoln (2011) misalnya, berpendapat tentang perlunya melihat cara peneliti merumuskan masalah dan menginterpretasi temuan penelitian untuk menimbang etis atau tidaknya sebuah riset. Menurut mereka, sebuah penelitian bisa menjadi problematik secara etis apabila perumusan masalah dan interpretasi hasil yang dilakukan dapat mengukuhkan ketidakadilan yang ada di masyarakat Dengan kata lain, meski sebuah penelitian telah dilakukan melalui prosedur yang etis, tetapi apabila kerangka berpikir yang digunakan mencerminkan sikap dan perlakuan yang tidak adil pada pihak atau kelompok tertentu, maka penelitian tersebut tetap dipandang bermasalah secara etis.

Argumen Cannella dan Lincoln (2011) di atas menunjukkan adanya cakupan tanggung jawab etis yang lebih luas. Hal ini senada dengan pendapat Lee-Treweek \& Linkogle (2000) yang memandang bahwa seorang peneliti bukan hanya bertanggung jawab pada individu atau kelompok yang dilibatkan dalam penelitian. Lebih jauh dari itu, peneliti memiliki tanggung jawab terhadap mereka yang bisa (secara langsung ataupun tidak), terdampak oleh hasil penelitian. Pemikiran semacam inilah yang terangkum dalam konsep epistemological violence (Teo, 2008, 2010, 2011a, 2011b), sebagaimana akan dipaparkan selanjutnya.

\section{Epistemological violence}

Melalui konsep epistemological violence (selanjutnya disingkat dengan EV), Teo $(2008,2010$, 2011a, 2011b) berargumen bahwa kerja dan karya 
ilmiah dapat menjadi media bagi terjadinya kekerasan simbolik pada individu atau kelompok yang menjadi fokus studi. Potensi kekerasan ters ebut terutama terkait dengan bagaimana peneliti melakukan interpretasi atas hasil penelitian. EV terjadi ketika melalui interpretasinya, peneliti memposisikan individu atau kelompok yang diteliti sebagai 'pihak yang inferior atau bermasalah' ('the inferior) problematic others'), dan kemudian hasil interpretasi tersebut diletakkansebagai pengetahuan yang faktual (Teo, 2010). Akibatnya, penelitian semacam ini dapat digunakan sebagai legitimasi ilmiah bagi terjadinya stigmatisasi, prasangka atau bahkan diskriminasi pada mereka yang diposisikan sebagai 'the inferior/ problematic others'. Berikut argumen Teo (2010) tentang hal ini.

\section{"Epistemological violence is a practice that is executed in empirical articles and books in psychology, when theoretical interpretations regarding empirical results implicitly or explicitly construct the Other as inferior or problematic, despite the fact that alternative interpretations, equally viable based on the data, are available" (hal.298)}

Teo (2010, 2011a, 2011b, 2015) mencontohkan EV dalam sejumlah studi psikologi yang menggunakan ras sebagai determinan pembeda potensi kognitif seseorang. Seorang peneliti yang melakukan studi semacam ini, bisa jadi menemukan bahwa rata-rata para responden dengan latar belakang ras $\mathrm{X}$ memiliki skor intelegensi yang lebih tinggi daripada para responden dengan latar belakang ras Y. Atas hasil ini, peneliti kemudian melakukan interpretasi bahwa tingkat intelegensi seseorang ditentukan oleh faktor genetik. Melalui cara interpretasi semacam inilah, seorang peneliti melakukan EV. Peneliti sebenarnya tidak memiliki data yang memadai untuk menarik kesimpulan tersebut. Peneliti hanya melakukan studi komparasi dan tidak meneliti kaitan antara faktor genetik dan intelegensi.

Menurut Teo (2011a), interpretasi semacam ini merupakan bentuk kekerasan simbolik karena menempatkan kelompok tertentu (dalam ilustrasi di atas ras Y) sebagai the inferior/problematic others. Terlebih lagi, dengan meletakkan ras sebagai variabel pembeda, secara tidaklangsung, peneliti menyampaikan gagasan bahwa suatu kelompok secara 'alamiah' memang lebih baik atau lebih buruk daripada kelompok yang lain. Disinilah tampak bagaimana suatu cara kerja dan karya ilmiah dapat menjadi legitimasi akademis bagi dikukuhkannya sistem dan praktek sosial yang diskriminatif pada kelompokkelompok tertentu.

Pemikiran Teo (2008, 2010, 2011a, 2011b, 2015) inilah yang menjadi latar belakang penulis untuk mencermati potensi EV dalam sejumlah penelitian psikologi sosial di Indonesia. Secara khusus, dalam tulisan ini penulis mengaitkan risiko EV dengan cara berpikir yang bersifat essentializing, sebagaimana dijelaskan dalam sub bab berikutnya.

\section{Essentialism}

Istilah essentialization (kadang disebut psychological essentialism) merujuk pada kecenderungan kognitif individu untuk mengelompokkan sekumpulan obyek yang dipandang memiliki karakteristik dasar yang sama dalam satu kategori (Bastian \& Haslam, 2006; Haslam, Bastian, Bain \& Kashima, 2006; Haslam \& Levy, 2006; Phillips, 2010). Setelah melihat berbagai jenis ikan misalnya, seseorang kemudian membuat kategorisasi tentang ikan berdasar karakteristik essensialnya, seperti hidup di air, bernafas dengan ingsang dan lain sebagainya.

Sebagai bagian dari kecenderungan kognitif individu, essentialization bisa jadi memang tidak terhindarkan. Bahkan dalam beberapa kasus, cara berpikir yang essentializing dapat digunakan untuk mendisrupsi proses kognitif yang mendasari stigma sosial. Penelitian Putra, Holtz, Pitaloka, Kronberger dan Arbiyah (2018) misalnya, menunjukkan bahwa positive essentialization berkorelasi negatif dengan stigma terhadap mantan tahanan politik dan keluarganya. Namun demikian, kecenderungan kognitif ini bisa menjadi problematik ketika dikenakan begitu saja pada sesuatu yang sifatnya tidak alamiah atau kodrati, namun merupakan hasil konstruksi sosial, politik dan budaya. Hal inilah yang mendasari sejumlah studi psikologi sosial mengaitkan kecenderungan essentialization dengan munculnya prasangka sosial (Bastian \& Haslam, 2006; Haslam, Rothschild \& Ernst, 2002). Guna mengelaborasi poin ini, penulis akan secara khusus mengacu pada pengertian essentialization yang dikemukakan oleh Phillips (2010).

Phillips (2010) mendefinisikan essentialism sebagai kecenderungan untuk mengasumsikan bahwa semua individu yang tergabung dalam satu kategori sosial yang sama akan memiliki karakteristik dasar yang serupa. Kecenderungan semacam ini misalnya tercermin dalam ungkapan 'perempuan pada dasarnya cenderung emosional' atau 'orang Jawa cenderung menghindari konflik'. Dalam dua ungkapan di atas terlihat bagaimana jenis kelamin dan etnisitas diposisikan sebagai satu kategori sosial yang menghasilkan individu-individu dengan ciri non-biologis yang sama.

Lebih lanjut, Phillips (2010) menyebutkan bahwa essentialism mengandung risiko sosial terkait dengan kecenderungan untuk mengasumsikan adanya karakteristik yang homogen dan menetap pada semua individu dari satu kategori sosial yang sama. Misalnya, seseorang dengan otomatis diasumsikan cenderung emosional karena dia seorang 
perempuan. Cara berpikir seperti ini memperbesar kemungkinan terjadinya over generalisation, mengukuhkan stereotip dan memperkecil kemungkinan seseorang bisa melihat adanya variasi karakteristik dalam kategori sosial tersebut (Phillips, 2010). Dalam praktek hidup sehari-hari, cara berpikir seperti inilah yang bisa mendasari terjadinya perilaku diskriminatif. Misalnya, seseorang yang berlatar belakang etnis X ditolak masuk di suatu lingkungan sosial karena diyakini ada karakteristik negatif yang homogen pada individu-individu bersuku X.

Ketika seorang individu memiliki karakteristik yang bertentangan dengan apa yang secara umum diyakini sebagai ciri dari kategori sosialnya, individu tersebut akan cenderung dipandang sebagai anomali dari kelompoknya. Lebih kecil kemungkinannya, hal semacam ini akan membuat orang mempertanyakan akurasi dari karakterisasi yang selama ini dikenakan pada kategori sosial tersebut. Disinilah tampak persoalan lain dari essentialism. Karakterisasi yang dilekatkan pada suatu kategori sosial cenderung dipandang sebagai sesuatu yang tak terelakkan atau pasti dimiliki semua individu pada kategori tersebut (Phillips, 2010). Dengan demikian karakterisasi yang merupakan produk sistem sosial, politik, dan budaya tertentu menjadi dipandang sebagai sesuatu yang melekat secara otomatis (atau bahkan alamiah), semata-mata karena individu yang bersangkutan berasal dari satu kategori sosial tertentu (Phillips, 2010). Sebagai implikasinya, individu atau suatu kelompok dapat diasumsikan secara inheren memiliki karateristik yang lebih superior atau inferior dibanding individu atau kelompok lain (Haslam, dkk., 2006; Haslam \& Levy, 2006; Phillips, 2010). Disinilah terlihat bagaimana essentialism dapat memicu munculnya sikap dan perilaku diskriminatif seperti yang disampaikan oleh Haslam dan Levy (2006).

\begin{abstract}
"Essentialist beliefs represent a set of ontological assumptions that capture some social categories better than others, that vary between people, and that appear to have important implications for attitudes ... essentialist thinking involves an inappropriate understanding of social categories as "natural kinds" so that groups that are in fact socially and historically constructed are misrepresented as akin to biological species ... essentialist beliefs legitimate and naturalize unequal social arrangements" (hal.471).
\end{abstract}

Argumen Haslam dan Levy (2006) di atas menggarisbawahi bagaimana essentialism dapat menjadi proses kognitif yang melegitimasi adanya ketidaksetaraan antar kelompok sosial. Berangkat dari pemahaman ini, banyak penelitian telah dilakukan untuk mengkaji keterkaitan antara essentialism dan prasangka (Bastian \& Haslam, 2006; Haslam, dkk., 2006; Haslam \& Levy, 2006; Wagner, Holtz, \& Kashima, 2009). Termasuk diantaranya sejumlah studi yang ditujukan untuk melihat bagaimana penelitian-penelitian di psikologi justru secara tidak langsung turut mereproduksi cara berpikir yang essentializing (Held, 2019; Howarth, 2008; Wainryb, 2004).

Salah satu contoh studi yang mengkritisi kecenderungan essentializing dalam penelitianpenelitian psikologi adalah studi tentang perbedaan gender yang dilakukan oleh Hyde (2005). Dalam studinya, Hyde mengkritisi kecenderungan psikologi untuk mereproduksi stereotip gender melalui penelitian-penelitian yang membandingkan perempuan dan laki-laki dalam berbagai aspek. Kebanyakan penelitian-penelitian semacam ini didasari asumsi tentang adanya perbedaan karakteristik inheren antara perempuan dan laki-laki. Padahal dari hasil meta-analis yang dilakukan pada ratusan studi komparatif yang membandingkan laki-laki dan perempuan, Hyde menemukan bahwa lebih dari $70 \%$ studi melaporkan nilai perbedaan yang hampir mendekati nol. Artinya sebagian besar studi kurang mampu menghasilkan temuan meyakinkan yang mendukung hipotesis tentang adanya perbedaan antara laki-laki dan perempuan dalam beragam aspek.

Studi seperti yang dilakukan Hyde inilah yang menunjukkan 'bahaya' dari cara berpikir yang essentializing. Perbedaan kecenderungan perilaku antara laki-laki dan perempuan yang merupakan produk pengondisian sosial-budaya dipandang sebagai sesuatu yang alamiah. Dalam sistem patriarki misalnya, cara pandang semacam inilah yang memberi legitimasi bagi dikukuhkannya ketidaksetaraan antara laki-laki dan perempuan. Dalam sistem ini, diasumsikan bahwa secara alamiah, laki-laki memiliki karakteristik essensial yang lebih superior daripada perempuan (Anderson \& Ahmed, 2003). Berangkat dari pemahaman semacam ini, maka diharapkan studi-studi di psikologi dapat lebih jeli mencermati cara berpikir essentializing yang ada di masyarakat dan tidak turut mereproduksinya melalui penelitian (Wainryb, 2004).

\section{Essentialism dan epistemological violence sebagai risiko etis dalam penelitian psikologi sosial}

Dalam artikel ini, penulis berargumen bahwa sejumlah penelitian psikologi sosial di Indonesia memiliki risiko etis berupa EV, karena menggunakan cara pandang yang essentializing. Penulis terutama menyoroti risiko ini dalam penelitian-penelitian komparatif yang meletakkan komponen identitas sosial (suku, ras) sebagai variabel pembeda (Basti, 2007; Candra, 2014; Lubis, 
2017; Wong, 2019). Termasuk dalam penelitian sejenis adalah skripsi yang dibimbing oleh penulis, berjudul "Prasangka sosial dan kecenderungan perilaku prososial pada etnis Jawa dan etnis Tionghoa" (Lie, 2008).

Menurut penulis, penggunaan cara pandang essentializing dalam penelitian-penelitian tersebut terlihat dari kecenderungan untuk mengasumsikan adanya karakteristik inheren dan homogen, yang melekat pada satu kategori sosial tertentu. Dengan menggunakan cara pandang yang essentializing, seorang peneliti dapat secara tidak langsung turut mengukuhkan prasangka dan diskriminasi yang ada di masyarakat. Proses seperti inilah yang dibaca oleh Teo (2008, 2010; 2011a, 2011b) sebagai bentuk kekerasan simbolik atau EV. Penulis akan menggunakan pengalaman pembimbingan skripsi untuk mengelaborasi argumen ini.

Skripsi yang dibimbing oleh penulis di atas, bertujuan untuk melihat perbedaan intensi prososial antara subjek penelitian yang berlatarbelakang etnis Jawa dan Tionghoa. Dalam literatur psikologi sosial, prososial biasanya dimaknai sebagai kedermawanan atau kesediaan menolong orang lain (Shadiqi, 2018). Melalui skripsinya, mahasiswatersebut hendak membandingkan niatan untuk bersikap prososial antar kedua kelompok subjek. Pilihan atas topik penelitian ini didasari pengalaman pribadi mahasiswa tersebut yang berulangkali dikenai prasangka tertentu karena beridentitas etnis Tionghoa, termasuk dalam soal kedermawanan. Kejengkelan atas pengalaman ini membuatnya ingin mengkaji dan mengkritisi persoalan prasangka rasial. Pada waktu itu sebagai dosen pembimbing, penulis tidak menyadari bahwa melalui penelitian semacam ini, kami justru tengah mereproduksi prasangka rasial yang dialami mahasiswa tersebut. Bertahun kemudian, penulis baru menyadari bahwa alih-alih mengkritisi prasangka antar etnis, melalui skripsi tersebut kami justru telah mereproduksinya dengan mengasumsikan bahwa dermawan atau tidaknya seseorang dapat ditinjau dari identitas etnisnya. Secara tidak langsung, melalui penelitian ini kami mengandaikan adanya pemaknaan tunggal tentang kedermawanan, sehingga subjek dari kedua kelompok etnis tersebut dapat diperbandingkan dengan menggunakan definisi, kriteria dan alat ukur yang sama. Ketika membimbing skripsi tersebut, penulis tidak menyadari cara pandang dan asumsi yang problematik ini. Terlebih, menimbang bahwa penelitian serupa cukup jamak ditemukan dalam riset-riset psikologi di Indonesia (Basti, 2007; Candra, 2014; Lubis, 2017; Wong, 2019).

Prasangka antar etnis dalam masyarakat Indonesia, khususnya pada mereka yang beridentitas etnis Tionghoa, merupakan produk dari sejarah panjang politik kekuasaan di Indonesia. Mulai politik stratifikasi golongan di era kolonial, hingga politik 'kambing hitam' di masa Orde Baru. Kesenjangan sosial yang disebabkan oleh cara kerja kekuasaan Orde Baru yang koruptif dan nepotistic justru direpresentasikan sebagai produk dari dominasi ekonomi oleh orang-orang Tionghoa. Akibatnya, berulang kali dalam sejarah Indonesia, orang-orang Tionghoa menjadi target prasangka dan kekerasan rasial (Lindsey \& Pausacker, 2005).

Dalam membimbing skripsi mahasiswa tersebut, penulis abai dengan faktor sejarah ini. Prasangka antar etnis justru semata-mata kami lihat sebagai persoalan yang lahir dari karakteristik esensial yang melekat pada identitas etnis subjek penelitian. Terlebih lagi, dengan mengoperasionalkannya dalam sebuah studi perbandingan, secara tidak langsung kami mengasumsikan bahwa setiapindividu secara inheren memiliki karakteristik yang lebih superior atau inferior dibanding individu lain, tergantung kelompok sosialnya (misalnya, etnis X lebih dermawan daripada etnis Y). Dengan kata lain, kami mengasumsikan adanya ketidaksetaraan yang bersifat alamiah (misalnya, sudah dari sananya begitu). Cara pandang semacam inilah yang oleh Haslam dan Levy (2006) disebut sebagai cara berpikir yang essentializing.

Haslam dan Levy (2006) menjelaskan bahwa cara pandang essentializing dapat menjadi dasar kognitif bagi munculnya prasangka, serta sikap dan perilaku yang diskriminatif. Dalam sejumlah penjelasan tentang prasangka dan diskriminasi (Dovidio, Hewstone, Glick, \& Esses, 2010), disebutkan bahwa memandang kelompok lain secara inheren lebih inferior merupakan proses kognitif yang mendasari munculnya sikap dan perilaku yang diskriminatif. Disinilah terlihat bagaimana melalui skripsi yang penulis bimbing, kami justru turut mengukuhkan prasangka rasial yang ada di masyarakat. Dengan kata lain, kami justru mereproduksi kekerasan simbolik atau EV dengan melakukan scientific racism (Teo, 2010).

Scientific racism adalah praktek dan karya akademis yang dibangun berdasar asumsi tentang adanya karakteristik genetik yang melekat pada setiap ras, termasuk untuk hal-hal yang bersifat nonbiologis (Richards, 2012). Asumsi inilah yang kemudian menjadi basis bagi dikukuhkannya hirakhi atau ketidaksetaraan berbasis ras. Sejumlah literatur (Richards, 2012; Teo \& Febbraro, 2003) telah mengulas bagaimana scientific racism menjadi salah satu persoalan etis yang mewarnai sejarah perkembangan psikologi sebagai sebuah disiplin. Salah satu contohnya yang populer adalah konsepsi tentang intelegensi sebagai aptitude yang ditentukan oleh ras (Teo, 2010). Konstruksi pengetahuan ini kemudian dijadikan legitimasi ilmiah untuk membuat stratifikasi superioritas-inferioritas berbasis ras.

Pemahaman inilah yang mendasari penulis untuk berargumen bahwa memproduksi epistemological violence melalui penggunaan cara pandang yang essentializing merupakan risiko etis yang perlu 
disadari dan dihindari dalam penelitian psikologi sosial. Seperti tercermin dalam pengalaman penulis, skripsi yang penulis bimbing menjadi ethically problematic bukan karena prosedur penelitiannya. Persoalan etik dalam penelitian tersebut muncul dalam bentuk scientific racism. Kami mengasumsikan bahwa sikap prososial seseorang ditentukan oleh karakteristik genetik yang melekat pada rasnya Hal ini terjadi karena ketidakmampuan kami untuk menimbang konteks historis yang melahirkan persoalan yang kami teliti. Akibatnya, kami abai pada implikasi sosial serta politis dari penelitian yang kami lakukan. Berangkat dari refleksi ini, pada bagian berikutnya, penulis akan mempaparkan argumen tentang pentingnya sikap reflektif dan pemahaman kritis atas etik penelitian.

\section{Reflexivity dan pentingnya pemahaman kritis atas etik penelitian}

Etik, dan khususnya etik penelitian dalam ilmu sosial, merupakan topik yang selalu bisa diperdebatkan. Unger (2016) meny ebutnya sebagai "highly contested topic" (hal. 88). Menimbang hal tersebut, penulis menyadari bahwa argumen dalam paper ini tentang essentialism dan epistemological violence, belum tentu dipandang sebagai tantangan atau isu etis yang relevan oleh beragam paradigma penelitian dalam ilmu psikologi. Paparan dalam tulisan ini cenderung merepresentasikan paradigma kritis dalam penelitian sosial yang beranggapan bahwa etis atau tidaknya sebuah riset sangat ditentukan oleh implikasi sosial dan politis yang ditimbulkannya (Cannella \& Lincoln, 2011; Macleod, Marx, Mnyaka \& Treharne, 2018; Sikes, 2013; Teo, 2018).

Cannella dan Lincoln (2011) merumuskan etik penelitian dalam perspektif kritis sebagai, "an ethics that is always/already concerned about power and oppression" (hal. 81). Dengan kata lain, perspektif kritis memandang bahwa tanggung jawab etis sebuah penelitian meliputi upaya untuk memastikan studi yang dilakukan tidak akan memproduksi atau mengukuhkan beragam bentuk ketidakadilan sosial (Cannella \& Lincoln, 2011; Mertens, dkk., 2009). Idealnya, melalui studi yang dilakukan, seorang peneliti justru dapat turut mempromosikan tatanan sosial yang lebih adil dan setara (Cannella \& Lincoln, 2011).

Perspektif kritis tentang etik penelitian ini sebenarnya sejalan dengan salah satu prinsip umum etik profesi psikologi, sebagaimana tercantum dalam beragam dokumen kode etik psikologi (American Psychological Association Ethics Code, 2017; Australian Psychological Society Ethics Code, 2007; Kode Etik Himpunan Psikologi Indonesia, 2010). Dalam berbagai dokumen kode etik tersebut terdapat rumusan umum tentang tanggung jawab sosial psikologi. Psikologi sebagai sebuah disiplin keilmuan, diharapkan dapat menghasilkan risetriset yang mempromosikan kualitas dan tatanan kehidupan sosial yanglebih baik.

Namun demikian, sebagai sebuah dokumen umum, rumusan kode etik biasanya tidak menjelaskan dengan detail bagaimana tanggung jawab sosial tersebut hendaknya dioperasionalkan. Pendekatan yang bersifat prosedural atas etik penelitian cenderung memaknai tanggung jawab sosial secara terbatas sebagai kewajiban peneliti untuk melindungi hak dan kesejahteraan subjek penelitian (DicksonSwift, James, Kippen, \& Liamputtog, 2008). Akibatnya, persoalan etis yang muncul dari implikasi penelitian pada konteks yang lebih luas, menjadi terabaikan (Cannella \& Lincoln, 2011).

Mengacu pada perspektif kritis terhadap etik penelitian, penulis mengajukan dua rekomendasi tentang bagaimana seorang peneliti dapat lebih peka membaca implikasi sosial dan politis dari riset-riset yang dilakukan. Pertama, penulis memandang pentingnya mengembangkan reflektivitas etis (ethical reflexivity) sebagai bagian dari proses penjaminan mutu penelitian. Kedua, penulis memandang perlunya pengembangan diskursus tentang etik penelitian yang lebih kritis, khususnya dalam ranah psikologi sosial. Kedua rekomendasi tersebut akan diuraikan lebih lanjut sebagai berikut.

Dalam perspektif kritis, memastikan etis atau tidaknya sebuah riset tidak berhenti pada aspek prosedural dari bagaimana suatu penelitian dilakukan. Lebih luas dari hal tersebut, isu etis menjadi orientasi pokok yang mengarahkan keseluruhan komponen dan proses riset, mulai dari bagaimana pertanyaan atau hipotesis penelitian dirumuskan hingga bagaimana temuan penelitian diinterpretasi dan didiseminasikan (Teo, dkk., 2014). Secara lebih khusus, orientasi etis tersebut diarahkan oleh pertanyaan-pertanyaan, seperti: "sejauh mana riset yang dilakukan (baik proses maupun hasilnya) mempromosikan tatanan sosial yang lebih adil dan setara?" atau "sejauh mana riset yang dilakukan tidak akan mengukuhkan opresi yang dilakukan kelompok/kekuatan dominan dan ketidakadilan yang dialami oleh mereka yang termarjinalkan di masyarakat?" (Roth \& Von Unger, 2018). Pertanyaanpertanyaan tersebut menjadi lebih krusial untuk direfleksikan ketika peneliti melibatkan individu atau kelompok yang tersingkir dan tertindas dalam risetnya (misalnya, individu difabel, kelompok minoritas, kaum miskin) (Mertens, dkk., 2009).

Pertanyaan-pertanyaan di atas seringkali tidak bisa dijawab dengan segera. Upaya menjawab pertanyaan-pertanyaan tersebut menuntut peneliti untuk menyadari sejarah akademis yang membentuknya, nilai dan asumsi yang diyakini, serta bagaimana hal-hal tersebut dapat memfasilitasi atau mereduksi kemampuannya melihat persoalan yang 
sedang diteliti secara kontekstual (Teo, dkk, 2014). Berangkat dari pandangan ini, penulis sepakat dengan sejumlah referensi (Gewirtz \& Cribb, 2006; Roth \& Von Unger, 2018; Teo, dkk., 2014), yang menegaskan pentingnya reflektivitas etis dalam proses penelitian. Reflektivitas etis adalah proses menyadari implikasi moral dan politis (yang secara langsung ataupun tidak) dapat ditimbulkan oleh cara peneliti mengkaji persoalan yang menjadi fokus riset (Gewirtz \& Cribb, 2006).

Menurut Teo, dkk. (2014), melakukan reflektivitas etis memerlukan kesediaan untuk mengenal beragam wacana historis, kultural dan politis yang melingkupi topik studi yang dikaji, terlebih-lebih dalam riset-riset di ranah psikologi sosial. Tanpa meletakkan topik serta individu atau kelompok yang dipelajari dalam konteks historis, kultural, dan politis yang membentuknya, akan sulit bagi seorang peneliti untuk menyadari bagaimana riset yang dilakukan bisa berdampak secara sosial dan politis. Seperti dikatakan oleh Gewirtz dan Cribb (2006), bahkan pada topik penelitian yang sangat apolitis sekalipun, sebuah riset selalu merepresentasikan posisi moral dan sikap politik tertentu.

Konteks historis, kultural, dan politis suatu masyarakatseringkali merupakan ruangyang penuh kontestasi, dikonstruksikan dalam beragam versi dan dibangun oleh berbagai determinan yang saling berkelindan (Reyes-Cruz \& Sonn, 2011). Maka, meletakkan topik studi dan partisipan penelitian dalam konteks historis, kultural, dan politis yang melingkupinya, menuntut kesediaan peneliti untuk mengenal beragam cara pandang dan narasi tentang konteks sosial dimana penelitian dilakukan. Proses semacam ini dipandang dapat membantu peneliti untuk membaca dengan lebih jeli beragam bentuk dan praktek kekuasaan, dominasi, serta marjinalisasi yang terjadi dalam masyarakat dimana penelitian dilakukan (Cannella \& Lincoln, 2011). Melalui proses inilah, peneliti akan terbantu untuk menimbang dengan lebih cermat posisi moral dan sikap politis yang akan diambil dalam riset yang dilakukan. Menurut perspektif kritis, posisi dan sikap yang diambil idealnya bukan yang akan memberi angin bagi segala bentuk penindasan dan ketidakadilan (Cannella \& Lincoln, 2011; Teo, dkk., 2014).

Seandainya kesadaran tentang pentingnya meletakkan topik studi dalam konteks historis, kultural, dan politis yang melingkupinya hadir dalam proses pembimbingan skripsi yang penulis lakukan, bisa jadi penulis akan merumuskan masalah secara berbeda. Alih-alih melakukan studi perbandingan antar kelompokuntuk menguji prasangka antar etnis terkait perilaku prososial, penulis mungkin justru akan berfokus pada prasangka antar etnis itu sendiri sebagai persoalan utamanya. Pertanyaan-pertanyaan berikutlah yang justru akan menjadi fokus perhatian: bagaimana orang melihat dan memaknai prasangka antar etnis terkait perilaku prososial, fungsi sosial apa yang dimainkannya dalam interaksi sehari-hari antar kelompok, struktur dan praktek sosial semacam apa yang memfasilitasi prasangka tersebut terus direproduksi dan untuk kepentingan apa atau siapa.

Pertanyaan-pertanyaan semacam ini membuka peluang yang lebih besar bagi penulis untuk memahami prasangka antar etnis sebagai sebuah pengalaman sosio-psikologisyang dikonstruksi oleh konteks politis, historis, dan kultural tertentubukan semata-mata sebagai sebuah disposisi alamiah yang melekat pada masing-masing kelompok. Berangkat dari pemahaman semacam ini, penulis barangkali justru akan mengarahkan mahasiswa tersebut untuk melakukan studi eksploratif tentang bagaimana konsep prososial dimaknai dan dikonstruksikan dalam budaya Tionghoa. Studi semacam ini berpeluang untuk menyuarakan cara pandang atau pemaknaan atas perilaku prososial yang barangkali selama ini tidak diberi tempat dalam konstruksi dominan tentang perilaku prososial. Terlebih ketika konstruksi dominan tersebut terus menempatkan kelompok tertentu sebagai 'the inferior others', studi eksploratif semacam ini bisa menjadi sebuah bentuk keberpihakan etis melalui upayanya untuk merepresentasikan suara dan pandangan yang kritis pada asumsi-asumsi dominan tentang perilaku prososial.

Terakhir, melalui artikel ini penulis hendak menggarisbawahi perlunya perhatian pada isu etik penelitian dalam upaya mengembangkan peta jalan penelitian psikologi sosial di Indonesia. Perspektif kritis atas etik penelitian, yang dijadikan rujukan utama dalam artikel ini, menekankan tentang tanggung jawab sosial peneliti untuk mempromosikan tatanan masyarakat yang lebih adil, sebagai kriteria utama praktek penelitian yang etis. Hal ini terutama diwujudkan melalui kerangka berpikir dan proses penelitian yang berpihak pada mereka yang tertindas dan tersingkirkan di masyarakat (Cannella \& Lincoln, 2011). Pandangan ini sebenarnya sejalan dengan apa yang sejak lebih dari sepuluh tahun lalu telah menjadi kegelisahan bersama di antara para figur senior psikologi di Indonesia. Sebagaimana terdokumentasikan dalam buku "Dialog psikologi Indonesia: Doeloe, kini dan esok" (Sarwono, dkk, 2007, hal. 176), sejumlah tokoh di bidang psikologi sosial menyerukan tentang perlunya "psikologi yang membela orang kecil, yang tidak status quo".

Berbagai bentuk ketimpangan sosial yang ada di masyarakat kita menegaskan masih relevannya kegelisahan para figur pendahulu tersebut Bagaimana generasi berikutnya di bidang psikologi sosial bisa menindaklanjuti kegelisahan ini? Melalui tulisan ini, penulis beragumen tentang perlunya mengembangkan dan mempromosikan etik penelitian yang berpihak pada mereka yang tertindas dan tersingkirkan. Orientasi etik semacamini bisa menjadi titik pijak untuk mengembangkan halhal berikutnya, seperti mengekplorasi kerangka teoritik dan metodologis yang dapat secara 
kontekstual mengoperasionalkan keberpihakan pada mereka yang tersingkir dan tertindas dalam riset-riset psikologi sosial di Indonesia.

\section{Penutup}

Dalam artikel ini, penulis mengulas epistemological violence sebagai risiko etis dalam sejumlah penelitian psikologi sosial di Indonesia. Secara khusus, penulis mengaitkan risiko ini dengan penggunaan cara pandang essentializing sebagai-mana tercermin dalam pengalaman pribadi penulis dan penelitian-penelitian lain yang melakukan studi komparasi, berbasis etnisitas atau ras. Dalam pandangan penulis, persoalan etis ini mencerminkan tantangan yang lebih luas, baik pada tataran personal maupun kolektif. Pada tataran personal, penulis berpendapat bahwa persoalan ini terjadi karena absennya proses reflektivitas etis dalam praktek penelitian. Sedangkan, pada tataran kolektif, penulis mengaitkan persoalan ini dengan perlunya mempromosikan orientasi etik akademis yang mendorong keberpihakan pada mereka yang tertindas dan tersingkirkan.

\section{Daftar Pustaka}

American Psychological Association. (2017). Ethical principles of psychologists and codeof conduct. Washington, DC: Author. Diakses dari https://www.apa.org/ethics/code/

Anderson, I. \& Ahmed, B. (2003). Sexism in psychology and how to end it: Feminist and critical debates in applied contexts. In R. Bayne \& I. Horton (Eds), Applied psychology: current issues and new directions. (pp. 172 183). London: Sage. https://doi.org/10.4135/9781446279151

Australian Psychological Society. (2007). APS code of ethics. Melbourne, Vic: Author. Diakses dari https://www.psychology.org.au/getmedia/d 873e0db-7490-46de-bb57-

c31bb1553025/APS-Code-of-Ethics.pdf

Azwar, S. (2017). Metode penelitian psikologi. Yogyakarta: Pustaka Pelajar.

Basti. (2007). Perilaku Prososial Etnis Jawa dan Etnis Cina. Psikologika, XII(23), 5 -68

Bastian, B., \& Haslam, N. (2006). Psychological essentialism and stereotype endorsement. Journal of Experimental Social Psychology, 42(2), 228-235. https://doi.org/10.1016/j.jesp.2005.03.003

Candra, K. E. (2014) Perbedaan tingkah laku menolong antara siswa etnis Jawa dan Tionghoa. Skripsi. Fakultas Psikologi, Universitas Katolik Soegijapranata
Cannella, G., \& Lincoln, Y. (2011). Ethics, research regulations, and critical social science. In $\mathrm{N}$. Denzin \& Y. Lincoln (Ed.), The Sage handbook of qualitative research 4 (pp. 81-90). Thousand Oaks, CA: Sage.

Dickson-Swift, V., James, E.L., Kippen, S., \& Liamputtong, P. (2008). Risk to researchers in qualitative research on sensitive topics: Issues and strategies. Qualitative Health Research, 18 , 133-144. https://doi.org/10.1177/104973230730900 7

Dovidio, J. F., Hewstone, M., Glick, P., \& Esses, V. M. (2010). Prejudice, stereotyping and discrimination: theoretical and empirical overview. In Dovidio, J. F., Hewstone, M., Glick, P., \& Esses, V. M. (Eds.), The SAGE handbook of prejudice, stereotyping and discrimination (pp 3-29). London: Sage Publications. https://doi.org/10.4135/9781446200919.n1

Gewirtz, S. \& Cribb, A. (2006). What to do about values in social research: The case for ethical reflexivity in the sociology of education. Bristish Journal of Sociology of Education, 27(2), 141-155 https://doi.org/10.1080/014256906005560 81

Guillemin, M., \& Gillam, L. (2004). Ethics, reflexivity, and "ethically important moments" in research. Qualitative Inquiry, 10(2), 261-280. https://doi.org/10.1177/107780040326236 0

Haslam, N., Bastian, B., Bain, P., \& Kashima, Y. (2006). Psychological essentialism, implicit theories, and intergroup relations. Group Processes \& Intergroup Relations, 9(1), 63-76. https://doi.org/10.1177/136843020605986 1

Haslam, N., \& Levy, S. R. (2006). Essentialist beliefs about homosexuality: Structure and implications for prejudice. Personality and Social Psychology Bulletin, 32(4), 471-485. https://doi.org/10.1177/014616720527651 6

Haslam, N., Rothschild, L., \& Ernst, D. (2002). Are essentialist beliefs associated with prejudice?.British Journal of Social Psychology, 41(1), 87-100. https://doi.org/10.1348/014466602165072

Held, B. S. (2019). Epistemic violence in psychological science: Can knowledge of, from, and for the (othered) people solve the problem? Theory \& Psychology, 0959354319883943. https://doi.org/10.1177/095935431988394 3 
Himpunan Psikologi Indonesia (HIMPSI). (2010). Kode Etik Psikologi Indonesia. Diakses dari https://himpsi.or.id/organisasi/kode-etikpsikologi-indonesia

Howarth, C. (2008). I hope we won't have to understand racism one day: Researching or reproducing race in social psychological research? British Journal of Social Psychology, 48(3), 407-426. https://doi.org/10.1348/014466608x36072 7

Hyde, J. S. (2005). The gender similarities hypothesis. American psychologist, 60(6), 581. https://doi.org/10.1037/0003066x.60.6.581

Israel, M. (2014). Research ethics and integrity for social scientists: Beyond regulatory compliance (2nd ed.). London: Sage Publications. https://doi.org/10.4135/97814 73910096

King, N. (2010). Research ethics in qualitative research. In M. A. Forrester (Ed.), Doing qualitative research in psychology. A practical guide (pp. 98-118). London: Sage Publication.

Knapp, S. J., \& VandeCreek, L. D. (2006). Practical ethics for psychologists: A positive approach. Washington DC: American Psychological Association. https://doi.org/10.1037/11331000

Lee-Treweek, G. and Linkogle, S. (2000). Overview, in G. LeeTreweek and S. Linkogle (eds.), Danger in the Field: Risk and Ethics in Social Research (pp. 1 - 7). London: Routledge.

Lie, T. P. (2008). Prasangka sosial dan kecenderungan perilaku prososial pada etnis Jawa dan etnis Tionghoa. Skripsi. Fakultas Psikologi, Universitas Katolik Widya Mandala Surabaya. URL: http://repository.wima.ac.id/3402/

Lindsey, T. \& Pausacker, H. (Eds.) (2005). The Chinese in Indonesia - Remembering, Distorting, Forgetting. Singapore: ISEAS Singapore and Monash Asia Institute.

Lubis, A. D. P. (2017). Perbedaan tingkat motivasi belajar siswa ditinjau dari etnis Tionghoa dan etnis pribumi di Yayasan Pendidikan Islam Amir Hamzah. Skripsi. Fakultas Psikologi, Universitas Medan Area

Macleod, C., Marx, J., Mnyaka, P., \& Treharne, G. J. (2018). Ethics in critical research: Stories from the field. In C. Macleod, J. Marx, P. Mnyaka, \& G. J. Treharne (Eds.), The palgrave handbook of ethics in critical research (pp. 113). London: Palgrave-MacMillan. https://doi.org/10.1007/978-3-319-747217_1

Mertens, D. M. \& Ginsberg, P. E. (Eds.). (2009). The handbook of social research ethics. Thousand Oaks, CA: Sage Publications.
Mertens, D. M., Harris, R. \& Holmes, H. (2009). Transformative research ethics. In D. M. Mertens \& P. Ginsberg, (Eds.), Handbook of social research ethics (pp. 85-102). Thousand Oaks, CA: Sage Publications.

Milla, M. N., Abidin, Z., \& Pitaloka, A. (Eds.). (2018). Psikologi Sosial: pengantar dalam teori dan penelitian. Jakarta, Indonesia: Salemba Humanika

Nagy, T. F. (2011). Essential ethicsfor psychologists: A primer for understanding and mastering core issues. Washington, DC: American Psychological Association. https://doi.org/10.1037/12345-000

Phillips, A. (2010). What's wrong with Essentialism? Scandinavian Journal of Social Theory, 11(1), 47-60.

https://doi.org/10.1080/1600910x.2010.96 72755

Putra, I. E., Holtz, P., Pitaloka, A., Kronberger, N., \& Arbiyah, N. (2018). Positive essentialization reduces prejudice: Reminding participants of a positive human nature alleviates the stigma of Indonesian Communist Party (PKI) descent.Journal of Social and Political Psychology, 6(2), 291-314. https://doi.org/10.5964/jspp.v6i2.794

Reyes-Cruz, M. \& Sonn, C. C. (2011). (de)colonizing culture in community psychology: Reflection from critical social science. American Joumal of Community Psychology, 47(1-2), 203 - 214. https://doi.org/10.1007/s10464-010-9378$\mathrm{x}$

Reza, I. F. (2016). Metodologi penelitian psikologi: Kuantitatif, kualitatif dan kombinasi. Palembang: Noer Fikri Offset.

Richards, G. (2012). Race, racism and psychology: Towards a reflexive history. London: Routledge. https://doi.org/10.4324/9780203131336

Roth, W. M., \& Von Unger, H. (2018). Current perspectives on research ethics in qualitative research. In Forum Qualitative Sozialforschung/Forum: Qualitative Social Research, 19(3), https://doi.org/10.17169/fqs-19.3.3155

Sarwono, S. W. \& Meinarno, E. A. (Eds.) (2009). Psikologi sosial. Jakarta: Salemba Humanika.

Sarwono, S. W., Markum, E., Matindas, R. W., Dahlan, W., Mansoer, W. W. D., Rumeser, J. A. A. ... (Eds.). (2007). Dialog psikologi Indonesia: Doeloe, kini dan esok. Jakarta: Himpsi Jaya.

Shadiqi, M. A. (2018). Perilaku Prososial. In A. Pitaloka, Z. Abidin, \& M. N. Milla (Eds.), Psikologi sosial, pengantar teori dan penelitian (227-260). Jakarta: Salemba Humanika.

Sikes, P. (2013). Working together for critical research ethics. Compare: A Journal of 
Comparative and International Education, 43(4), 516-536. https://doi.org/10.1080/03057925.2013.79 7765

Supratiknya, A. (2015). Metodologi penelitian kuantitatif \& kualitatif dalam psikologi.Yogyakarta: Sanata Dharma University Press.

Sutojo, N. N., \& Hidajat, L. L. (2018). Etika psikologi: Menilik nurani psikologi Indonesia Jakarta: Kompas

Teo, T. (2008). From speculation to epistemological violence in psychology: A critical-hermeneutic reconstruction. Theory \& Psychology, 18(1), 47-67. https://doi.org/10.1177/095935430708692 2

Teo, T. (2010). What is epistemological violence in the empirical social sciences?. Social and Personality Psychology Compass, 4(5), 295303. https://doi.org/10.1111/j.17519004.2010.00265.x

Teo, T. (2011a). Empirical race psychology and the hermeneutics of epistemological violence. Human Studies,34(3), 237-255. https://doi.org/10.1007/s10746-011-91798

Teo, T. (2011b). Theory and empirical research: Can scientific ideas be violent? In P. Stenner, J. Cromby, J. Motzkau, J. Yen, \& Y. Haosheng (Eds.), Theoretical psychology: Global transformations and challenges (pp. 239246). Concord, ON: Captus

Teo, T. (2015). Are psychological "ethics codes" morally oblique? Journal of Theoretical and Philosophical Psychology, 35, 78-89. https://doi.org/10.1037/a0038944
Teo, T. (2018). Should psychologists care about injustice? In T. Teo, Outline of theoretical psychology(pp. 201-218). London: Palgrave Macmillan. https://doi.org/10.1057/978-1137-59651-2_9

Teo, T., \& Febbraro, A. (2003). Ethnocentrism as a form of intuition in psychology. Theory and Psychology, 13 (5), 673-694. https://doi.org/10.1177/095935430301350 09

Teo, T., Gao, Z., \& Sheivari, R. (2014). Philosophical reflexivity in social justice work. In C. V. Johnson \& H. Friedman (Eds.), The Praeger handbook of social justice and psychology (pp. 65-78). Santa Barbara, CA: Praeger.

Unger, H. (2016). Reflexivity beyond regulations: Teaching research ethics and qualitative methods in Germany. Qualitative Inquiry, 22(2), 87-98. https://doi.org/10.1177/107780041562022 0

Wagner, W., Holtz, P., \& Kashima, Y. (2009). Construction and deconstruction of essence in representating social groups: Identity projects, stereotyping, and racism. Journal for the Theory of Social Behaviour, 39(3), 363383. https://doi.org/10.1111/j.14685914.2009.00408.x

Wainryb, C. (2004). The study of diversity in human development: Culture, urgencies and perils. Human Development, 47(3), 131 - 137. https://doi.org/10.1159/000077986

Wong, C. (2019). Perbedaan strategi coping pada mahasiswa baruetnisJawa dan etnis Tionghoa. Skripsi. Fakultas Psikologi, Universitas Katolik Soegijapranata. 